Journal of Mechanical, Civil and Industrial Engineering

ISSN: $2710-1436$

DOI: $10.32996 /$ jmcie

Journal Homepage: www.al-kindipublisher.com/index.php/jmcie

\title{
Detention Reservoir: Proposal for Flood Control in the Ipiranga Stream Basin, Juiz de Fora MG, Brazil
}

\author{
Henrique da Silva Pizzo ${ }^{1,2} \square$ and Vinícius Martins Galil ${ }^{1}$ \\ ${ }^{1}$ College of Civil Engineering, Estácio University of Juiz de Fora, MG, Brazil \\ ${ }^{2}$ Department of Hydraulic Measurements, Municipal Water and Sewage Company of Juiz de Fora, Brazil
}

$\square$ Corresponding Author: Henrique da Silva Pizzo, E-mail: henriquepizzo.estacio@gmail.com

\begin{tabular}{ll}
\hline ARTICLE INFORMATION & ABSTRACT \\
\hline
\end{tabular}

Received: 10 October 2021

Accepted: 22 November 2021

Published: 05 December 2021

DOI: 10.32996/jmcie.2021.2.1.6

\section{KEYWORDS}

Ipiranga Stream basin, detention reservoir, flood damping, flood routing
In order to provide parameters for sizing a damping reservoir, which was intended to control the floods that occur in the Ipiranga Stream basin, a routine developed in Visual Basic for Applications (VBA) is used. From the identification of the most critical point of the flood, hydrological flow data are presented, estimated by dividing the basin into sub-basins, using the Rational method, resulting in a value of flow higher than the admissible one for the stream channel. The method used in dimensioning the reservoir was flood routing. After making a pre-selection of the most interesting place to position the reservoir, insertions of the situation existent were made to the VBA application, in order to generate scenarios and enable the choice of an ideal situation, in view of the presented constraints. A very acceptable and feasible result is pointed out, indicating general parameters for sizing a reservoir to control floods in the Ipiranga Stream basin.

\section{Introduction}

The amount of impermeable soil and alterations in natural drainage systems are increasing as a result of the fast growth of metropolitan areas. As a result of the difficulty of rainfall infiltration, there is a significant rise in surface discharges, favoring the occurrence of floods (Kessler \& Diskin, 1991).

It is advantageous for the community if the urban area is designed in an integrated manner, that is, if all public works are planned in a consistent manner. When the drainage system is not included from the beginning of the urban planning formulation, it is extremely likely that when developed, it will be both expensive and inefficient. System planning must be carried out in accordance with well-defined standards, while constantly taking into consideration local, physical, economic, and social characteristics. The objective must be a realistic, technically and economically efficient drainage system project that maximizes advantages while reducing costs is compatible with other sector plans, and meets the needs of the community Fugita, (1986).

For many years, a lack of urban planning allowed cities to flourish in a haphazard, occasionally chaotic manner, particularly in big urban areas. As a result, certain urban places were occupied and overused, with no infrastructure to offer performance that was acceptable with the mandated standards. Such events continue to occur in enormous numbers today, generating a variety of issues, the most prominent of which is urban flooding. To address the flood problem, it is common to consider expanding the drainage system. However, this is not always feasible, either monetarily or for other reasons, necessitating the use of alternate solutions.

\section{Literature Review}

\subsection{Flood dampening reservoirs overview}

Temporary storage reservoirs are highly effective in reducing discharges in a portion of the urban drainage gallery system because they encourage the partial retention of runoff from rainfall. They are built interspersed in the network and store the pluvial flow during part of the concentration period of the upstream gallery, gradually discharging it in the downstream gallery, limiting the

Copyright: (c) 2021 the Author(s). This article is an open access article distributed under the terms and conditions of the Creative Commons Attribution (CC-BY) 4.0 license (https://creativecommons.org/licenses/by/4.0/). Published by Al-Kindi Centre for Research and Development, London, United Kingdom. 
flow in this last conduit; this fact allows for the reduction of its dimensions, in the case of a project, or the attenuation of floods in more critical situations. Because of their storage capacity, reservoirs offer the most uniform possible flow, which adds to the gallery system's improved performance by minimizing the high peaks of flood waves caused by waters precipitated in heavy rain Wilken, (1978).

As structures for releasing the collected quantities, these reservoirs frequently feature orifices or spillways. In general, orifices are used to discharge lower quantities than spillways. As a result, when designing reservoirs to manage runoff from rainfall with recurrence durations ranging from 10 to 100 years, both structures are typically used together. Smaller floods are mitigated by discharges via orifices, while severe rainfall trigger spillways.

Akan (1989) underlines the significance of selecting an appropriate recurrence time as a critical component for damping reservoirs to work properly. Another research is given in his essay, addressing the fact that if a 100-year rainfall is used for detention reservoir dimensioning, the effect of lowering the flood peak for considerably smaller rains will be minimal. In the other case, if a 10-year rainfall is used for sizing, the 100-year rainfall will flow through the reservoir with a discharge peak that is far larger than the projected rate.

According to Abt \& Grigg (1978) experience has demonstrated that detention reservoirs should not be built arbitrarily in basins since, instead of alleviating, they might exacerbate the danger of big floods when not considering all possible impacts. To ensure optimal efficiency in the process, buffer reservoirs must be connected with contributing basins and regional strategies for controlling big flows from rainfall. Estimates of the storage volumes required to limit flood flows to desired levels are frequently required in rainfall studies. These estimations are important in locating and assessing possible locations for detention reservoir placement (McEnroe, 1992). For the control of specifically urban floods with relatively small flows, the issue of reservoir positioning primarily consists in reconciling ideal locations conducive to optimal system functioning with areas where there is available space and topographical conditions favorable to project implementation.

\subsection{Flood routing}

In reservoirs, the procedure known as flood routing consists of computing accumulated water levels, stored volumes, and discharged flows, all of which correlate to a specific influent hydrograph, in order to validate the reservoir's influence in damping floods (Creager et al., 1945). When a flood wave enters a reservoir, the water level rises, increasing the amount accumulated. The discharge via orifices and weirs increases as the level rises, however not as much as the increase in influent flow. The procedure is repeated until the peak of the inflow is achieved, and if it remained constant for some time (which it does not owe to the form of the hydrograph), the highest value of the outflow would be the same as inflow. From then on, the inflow hydrograph drops, while the fall in outflow is more gradual, to the point where the outflow exceeds the inflow. The reservoir temporarily stores a volume of water during the procedure. Depending on reservoir size and storage capacity, the effluent hydrograph will have a much lower peak than the influent hydrograph. As a result, flood damping is characterized.

According to Basha (1994), while numerous functions may be employed to describe the influent hydrograph, the usage of basic functions is more useful for modeling purposes. The triangle hydrograph, which is widely used in engineering analysis and design, is the simplest known function. Basha (1995) reiterates that the use of a triangular distribution has been proved to be a reasonable simplification for most tributary hydrographs with a single flow peak since required connections between ascending and descending curve branches are observed.

The mathematical expression of flood routing in reservoirs is provided by combining the continuity equation with the flow equation in the reservoir discharge structures, resulting in a non-linear differential equation known as the routing equation. In the lack of an analytical model for this equation, numerical approaches, graphic and semigraphic methods, and approximate analytical solutions are applied, often utilizing trial procedures (Kessler \& Diskin, 1991).

\subsection{Studies, researches, and applications}

Shrestha \& Kawasaki (2020) concentrated on the quantitative evaluation of flood danger and risk, including the efficacy of dam operation for flood protection. For analysis, a grid-based methodology incorporating the following was used a hydrologicalhydraulic model, a technique considering dam operation for flood management, and an evaluation of flood damage. To assess the risk, flood characteristics were computed using the rainfall-runoff-inundation hydrological-hydraulic model, and flood damage was assessed by integrating the flood characteristics, flood damage curves, exposure characteristics, and property values. The danger was evaluated by focusing on flood damage to residential buildings and assets, as well as agricultural sectors, in the most recent floods and flood episodes with varying return durations. The Bago River basin in Myanmar was studied for this project. According to the findings, dam operation for flood control in the research region lowers flood inundation area by about $10 \%$ and flood damage to dwellings, assets, and crops by about $40 \%, 60 \%$, and $10 \%$, respectively. 
The Forecast-Optimization-Decision Making (FODM) chain is outlined by Zhu et al. (2017) as the major phases in optimum flood control decision making. A system is developed to facilitate effective flood control decision-making under numerous uncertainties and to analyze risk propagation along the FODM chain holistically. Stochastic models are used at each step of the FODM chain to cope with uncertainty. Multi-objective stochastic programming with a recourse model for optimum flood control operation is established using synthetic ensemble flood predictions made using the martingale model of forecast evolution. The constraint technique combined with a two-step procedure is used to determine the Pareto front under uncertainty. A unique SMAA-TOPSIS model for stochastic multi-criteria decision-making is proposed. Advances proposed include a risk assessment model, the risk of decision-making mistakes, and the rank uncertainty degree to quantify the risk propagation process throughout the FODM chain. Numerical experiments are being carried out to study the implications of flood forecast uncertainty on optimum flood control decision making and risk transmission. The proposed approach is being used to a flood control system in China's Daduhe River basin. The results show that the suggested technique may give useful risk information in each link of the FODM chain, allowing for more reliable risk-informed decisions.

The primary goals of Rong et al. (2019) are to look at the hydraulic properties of the dam discharge flow and its downstream influence. To produce the terrain entity and hydraulic structures, building information modeling technology is used. The dam discharge and flood routing simulation are calculated using Reynolds-Averaged Navier-Stokes equations with the RNG k- $\varepsilon$ eddy viscosity model for turbulence closure and the Volume of Fluid technique. The model accuracy is evaluated using an urban flood experiment and field measurement data. The flow field is obtained in order to evaluate the dam's operational characteristics at various water levels. The maximum downstream flow depth, maximum discharge capacity, and hydraulic leap length are $18.6 \mathrm{~m}$, $13,800 \mathrm{~m}^{3} / \mathrm{s}$, and $108 \mathrm{~m}$, respectively, under the normal water level. The dam meets the safety need at various water levels, although special care should be made to the dam foundation, particularly near the discharge flow incident areas. Three-dimensional simulation can represent complex turbulent flow patterns such as collision, reflection, and vortex. The numerical simulation may greatly aid reservoir management in ensuring the stability of the dam's functioning.

On the basis of interviews with public and other municipal authorities in the state of Minas Gerais, Brazil, Milograna et al. (2013) aim to present a procedure for assessing direct damages caused by floods at urban infrastructure, including water supply, drainage, sanitary and electrical distribution systems, road networks, and urban solid waste management. To solidify the suggested systematics, it was applied to Itajubá city, for which floods were simulated for 10, 50, and 100 years of return duration, as well as their corresponding damages. The findings revealed that, under the constraints imposed by the difficulties of getting and processing data, and the establishment of a link with parameters of inundation, urban infrastructure damages account for approximately $10 \%$ of all direct damages.

Using hydrographs pushing a flood control reservoir, Balistrocchi et al. (2017) describe an excellent technique for describing the statistical relationship between peak flow discharge and flood volume. A 52-year time series of flow discharges recorded in the Panaro River (Northern Italian Apennines) is used to fit an event-based bivariate distribution and to facilitate time-continuous modeling of an online flood control reservoir along with the river system. In terms of reservoir performance, an analytical approach for predicting the bivariate return duration is created using the derived distribution theory and a reduced routing scheme. The return period in this strategy is that of the peak flow discharge discharged downstream from the reservoir. As a result, in order to validate the proposed method's dependability, a nonparametric version of its frequency distribution is tested using continuous simulation statistics. The downstream peak flow discharge copula generated and nonparametric distributions are found to be in good agreement. Finally, a comparison of bivariate return period estimates obtained using various methodologies is shown.

An optimal flood control operation model of cascade reservoirs for particular flood control sites downstream has been presented for the effective utilization of reservoir storage (Zhou et al., 2018). In the suggested model, the upstream reservoirs with the best operating strategy were evaluated to lower the input of the reservoir downstream. Flood route and time lag cannot be ignored in a wide river basin. As a result, the DP-POA approach, which combines dynamic programming (DP) and the progressive optimality algorithm (POA), was introduced. The study's originality is to present a two-stage optimum reservoir operation model with a DPPOA algorithm to handle the problem of optimal cascade reservoir cooperation for numerous flood control locations downstream during the flood season. As a case study, the upper Yangtze River was chosen. Three reservoirs in the upper Yangtze River, Xiluodu, Xiangjiaba, and the Three Gorges reservoirs (TGR), were considered from upstream to downstream. The results show that the twostage optimization technique performs well in handling the cascade reservoirs optimization issue, as the inflow of reservoir downstream and division volumes were significantly decreased. The average decrease of flood peak for all 13 typical flood hydrographs (TFHs) after optimal functioning of Xiluodu and Xiangjiaba reservoirs is 13.6 percent. Meanwhile, the cascade reservoirs can store far more stormwater during a flood event, with maximum volumes held in the two reservoirs upstream in our research reaching 25.2 billion $\mathrm{m}^{3}$ during a flood event. When the suggested technique is combined with the present operating method, the findings show that flood diversion volumes at flood control locations along the river reduce substantially. 
The results of modeling the regulation of flood flow in a river basin by a flood control facility on a side tributary of the river under climatic change circumstances are discussed by Antonov et al. (2019). When justifying their parameters, the use of a geographic information system is suggested for measuring the impact of flood control systems on the environment. The necessity for antiflood hydro systems on side tributaries exists because the water capacity of current and planned hydro systems may not be sufficient to convert floods in the face of economic and climatic changes. The issue comes in estimating the needed water capacity of the flood control facility and its placement while taking environmental constraints into account.

Based on Muskingum flood routing in the aggregation approach, Gong et al. (2019) conceptualize channel flood routing as a virtual channel storage reservoir (CSR). The dynamic control boundaries for the multi-reservoir water level during flood seasons (WLFS) are then derived using the aggregation-decomposition method: the aggregation reservoir is created by taking into account channel storages, and flood risk is quantified using pre-discharge rules, and the aggregated reservoir storages are decomposed by maximizing hydropower generation with constraints. A case study was chosen for the Xiluodu, Xiangjiaba, and Three Gorges reservoir systems on the Yangtze River in China. When static operation conditions are used, yearly electricity generation is 175.40 billion kWh. If CSRs were not taken into account, the output would be 177.05 billion kWh with the dynamic operation and 177.53 billion $\mathrm{kWh}$ with CSRs taken into account. As a result, the suggested technique can calculate the dynamic control boundaries for the multi-reservoir WLFS with high efficiency.

Silva et al. (2014), Augusto (2008), Martins (2006), and Silva et al. (2013) present and discuss the use and operation of flood damping reservoirs, for urban situations, in the cities of Lauro de Freitas, Rio de Janeiro, São Paulo, Uberaba, with a focus on methods of sizing and projects, and efficiencies obtained. Issues of unavailability of spaces, government programs, and political issues in general, multiple uses when the reservoir is emptied, situations of possible accumulation of waste and pollution, and costs and disbursements are addressed. A comparison among the cases of the last 3 cities mentioned is made by Penna et al. (2019).

As stated by Souza (2018), Brazilian urban drainage is deemed obsolete since the notion of canalization takes precedence over reservation and infiltration, preferring quick drainage over-regulated disposal of conserved volumes. The study proposes a dimensioning approach that establishes criteria that tie the impermeable portions of the lots to the dimensioning parameters of the reservoirs, ensuring the operation of this control measure for the city of Curitiba. Given that the reservoirs must allow the given impermeable area to return to its pre-urbanization condition in terms of contribution flows, the necessary value to reduce the peak flow by 70.24 percent in the studied situation was estimated using the relationship between the runoff coefficients in both waterproofing conditions. Graphs of the geometric properties of the reservoirs were created as a function of the contribution flow that each generic region gets from flow propagation simulations using the Puls method in generic waterproofed areas at constant intervals used in the study. Based on their behavioral analysis, sizing formulae for the parameters of volume, base area, water depth height, and flow regulator orifice diameter were given, matching them to the impermeable regions present, ensuring efficiency. The bare minimum. When the results obtained are compared to those provided for in municipal legislation, there is a condition for a reduction of 24.14 percent in volume in relation to the calculation in question, in addition to the possibility of improving the efficiency of the reservoirs with the use of other dimensioning parameters.

Using a mathematical hydrological model of precipitation flow, six types of reservoirs implanted in typical and subjected to increases in impermeable regions lots of the city of Porto Alegre were analyzed (Cruz et al., 1998). The required volumes of implantation and maintenance expenses were determined using the typical precipitations of micro drainage and the hydraulic behavior of each device. The results revealed that for the biggest simulated lot, $600 \mathrm{~m}^{2}$, with $100 \%$ waterproofing, quantities in the range of 2.5 to $3.0 \mathrm{~m}^{3}$ would be required, and for $50 \%$ waterproofing, volumes in the region of 1.0 to $1.5 \mathrm{~m}^{3}$ would be required.

Francischet \& Alamy Filho (2011) investigate the attenuation impact of household rainwater storage reservoir implementation in a typical square using Visual Basic for Applications (VBA) programming, where two damping volumes for the storage device in batch condition settings were built. The household reservoir was sized for initial rains of 05 and 10 year return period and tested for maximum project rains of $02,05,10,15,20,25,50$, and 100 year return period, of which the temporal distribution used was the largest storm recorded in the Municipality of Uberlândia in 2006, referring to the year 2006. The detention reservoir with a damping volume of $3.25 \mathrm{~m}^{3}$ provided attenuation, at the end of the simulated stretch, of $37.38,24.02,21.74,20.99,18.51,16.70,11.73$, and 7.52 percent, for the rains $02,05,10,15,20,25,50$ and 100 year return period, respectively, while for the detention reservoir with a damping volume of $5.015 \mathrm{~m}^{3}$ the attenuation was $64.72,65.10,63.96,63.23,62.71,62.32,61.11$, and 59.98 percent.

Vanijjirattikhan et al. (2021) describe the development of reservoir flood routing modeling software with spillway operating rules that are understandable and customizable by the spillway operator. The program is a component of the Dam Safety Remote Monitoring System used by Thailand's Electricity Generating Authority. A storage-indication routing approach, which is a hydrologic method, is used to implement the flood routing simulation. The spillway operating rules are displayed in a tree-based structure, with the spillway gate opening determined by the present reservoir water level (RWL), spillway gate opening, and flood 
condition if the peak inflow has passed. The findings of the simulation reveal that the simulated RWL is identical to the RWL data in the dam-building handbook. This validates the correctness of the reservoir flood routing simulation, which is useful for spillway operations planning.

The routing equation is achieved by coupling the continuity equation in reservoirs, in its average form via integration by finite differences, taking sufficiently small time intervals, with the flow equation in the discharge structures, whether orifices or weirs (Galil \& Pizzo, 2021). This is solved numerically, by iterations, in order to obtain the outflow of the reservoir for each time interval, with the final quantities of a given interval being transferred to the initial quantities of the following interval, until the effluent hydrograph is generated. From there, the value of the maximum outflow is contrasted with that of the maximum inflow, in order to verify the reservoir's damping potential. Retries can be performed until the optimal result is reached. The tributary hydrograph is adopted as triangular, and the rise time and descent time ratio can be arbitrated by the user of the application, as well as the definition of the number of time intervals, in order to obtain greater precision in the results. For the influent hydrograph construction, maximum inflow and time of concentration are verified. The computational application lends itself to dimensioning situations, and also for checking the sufficiency of areas for the desired damping and maximum heights reached by the available water. A device is included to replace the single orifice option with the possibility of using multiple orifices while maintaining the same discharge capacity. All procedures are performed by a VBA application.

For the modeling of the flood runoff and routing process of the transboundary Arda River basin, a particular software program has been developed by Angelidis et al. (2018). The software application takes into consideration the existence of three cascade Bulgarian reservoirs with the goal of flood prevention and power optimization. At the start of the simulation, inflow estimates for the next five days and initial water levels in the three reservoirs are input. The management tool incorporates all of the different operating modes of hydropower plants, water discharged from spillways, and river and reservoir flow parameters in order to optimize the whole system (power output and flooding costs) during the flood event. The created software is also an effective tool for establishing a flood warning system.

The flood routing process was employed to present a system developed in Turbo Pascal 5.5, which simulates the behavior of flood damping reservoirs. Discharge structures contemplated are orifices and spillways. The input data in the software are the maximum influent flow, the reservoir bottom area, the type and dimension of the discharge structure; and the output data are the flood damping ratio, the maximum water height reached in the reservoir, and the time required for its download. The simplification of the triangular inflow hydrograph was used, with a ratio between rising time and descent time of 1:2.3, representative of urban flows (Pizzo, 1997). Cicolani \& Pecini (2019) present a program developed in VBA and, in order to demonstrate its functionality, it is applied to the case study of the Pacaembu reservoir, located in São Paulo city, demonstrating consistent results compared to real data and to other programs, and performing fast calculations.

\subsection{Ipiranga Stream basin}

Silva \& Machado (2011) give a case study on the occurrences of floods recorded in the Ipiranga Stream basin, intending to identify the areas where environmental problems induced by floods occur, resulting in material damages for the local people. Field visits, morphometric analysis, and map editing were carried out using the ArcGis 9.3 program, which assisted in verifying the existing contrast between land use and terrain, as well as the form of the basin and urban occupancy. These criteria, according to work, are significant variables in planning, organizing, and building a city that is more adapted to both environmental and citizen demands. A comprehensive diagnosis of the drainage system in the northern area of the municipality of Juiz de Fora is presented by the City Hall of Juiz de Fora et al. (2011). The study was carried out based on the registration of sub-basins, the realization of flood spot simulations, the relevant legislation on urban planning and land use, various urban development plans and programs that had been, or were being, implemented in the region.

It is exposed and discussed by Gerheim (2016) a city of Juiz de Fora's notable and growing problem: the occurrences of overflows, flash floods, and inundations, in order to relate the challenges imposed by urban expansion today with the importance of water resources for human development and its fundamental importance in the environmental context. In this regard, from 2000 to 2014, the occurrences confirmed in the watersheds of the São Pedro and Ipiranga Streams were examined. The study assesses these data and links them to the land use and habitation models of these basins in 1983,2007, and 2016, and it also examines the state of the Permanent Preservation Areas in 2016. The intersection indicates an increase in the rates of occupied areas in the mentioned spatial cutouts, which are $26.7 \%$ in the São Pedro Stream basin and $28.9 \%$ in the Ipiranga Stream basin, while the quantities of forest remnants total $22.2 \%$ in the first basin and $35.2 \%$ in the second. Ultimately, several possibilities for mitigating these events are provided and explored, emphasizing the importance of the involvement and participation of official agencies in their many areas, as well as civil society. 
A survey of the hydrological flow in the Ipiranga Stream basin was carried out by Galil et al. (2021). Initially, through a series of site visits and gathering details with the basin population, the point where the highest occurrence of flooding in the basin was detected, which is the confluence point between the two largest local avenues, where the Stream turns and the channel is closed. From then on, the hydrological flow was obtained from a scheme of dividing the basin upstream of the curve point into several sub-basins, as shown in Fig. 1 where the analyzed point is indicated.

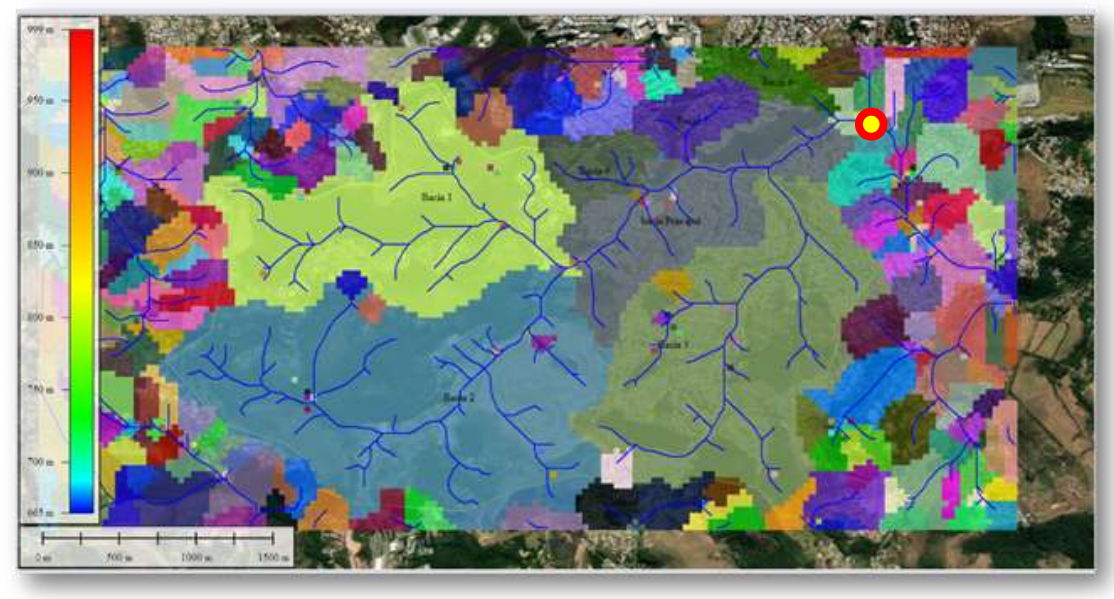

Fig. 1. Ipiranga Stream sub-basins and point of flood

Global Mapper and Google Earth software were used in order to delimit the sub-basins. To determine the flow in them, the Rational method was used, with the time of concentration was calculated using the Ven Te Chow formula. A 20-year recurrence interval was considered. The travel times in the channel were taken into account, as shown in Fig. 2.

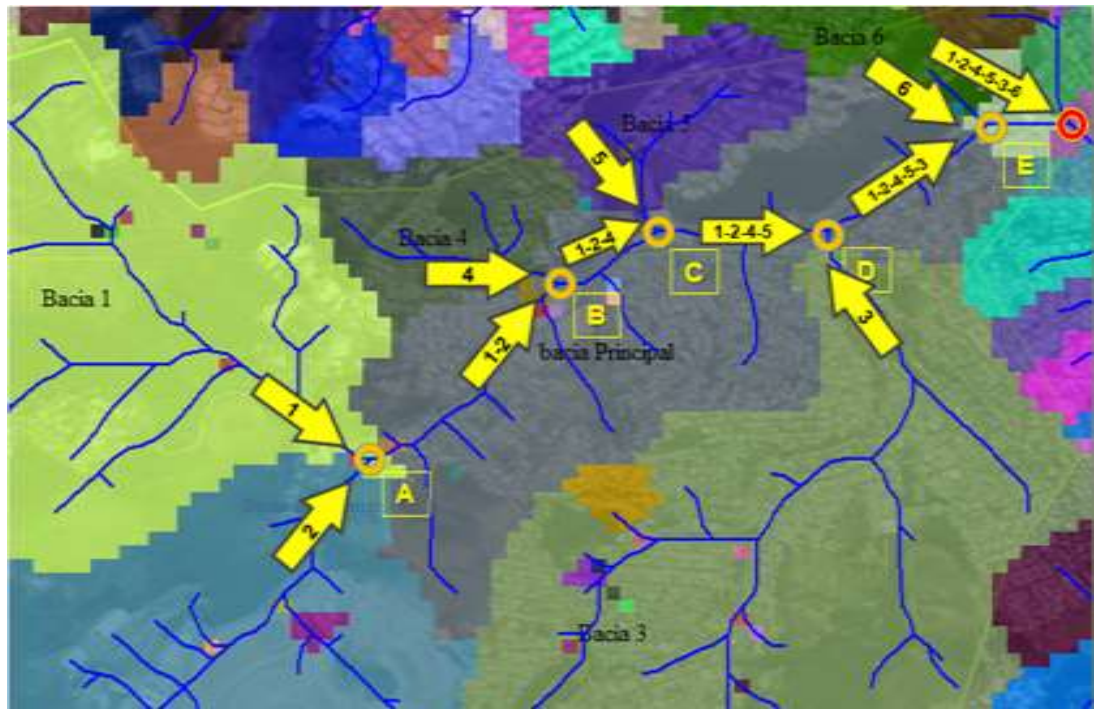

Fig. 2. Calculus scheme for travel times on the main channel

Finally, the maximum flow rate of approximately $174.0 \mathrm{~m}^{3} / \mathrm{s}$ at the point of the curve was obtained. Through the Manning formula, with the channel's bottom slope previously raised by local government agencies, and geometric and roughness of the walls and bottom of the stream channel characteristics measured, it was verified that the channel has a maximum discharge capacity of 97.5 $\mathrm{m}^{3} / \mathrm{s}$, smaller than the current peak flow, which corroborates the flood situation.

\section{Methodology}

The general VBA application described by Galil \& Pizzo (2021) was applied to the Ipiranga Stream situation, presented by Galil et al. (2021), in order to dimension and position a detention reservoir, in order to solve the flood problem. The region is very dense, with little vacant land, which makes it very difficult to find an ideal place to position such a reservoir. Attempts were made to position it in such a way that the flow of the sub-basins upstream of the reservoir, dampened by the same, added to the original 
flows of the sub-basins downstream from that, did not exceed the maximum flow allowed by the channel. For each trial, different parameters (inflows, available areas, etc.) were inserted in the application.

The area located just downstream of the two large headwater sub-basins was identified as quite interesting, due to the fact that it presents a low occupational density, practically eliminating any need for property expropriation. Furthermore, because of the premise that the sub-basins upstream to this point have very considerable areas, with high flow production, it makes them presents a strong potential for damping. Such an area is indicated in Fig. 3.

From this identification, it was verified that the flow of the two sub-basins upstream of the chosen point generated a flow in the order of $114.0 \mathrm{~m}^{3} / \mathrm{s}$. Knowing that the maximum flow at the flood point (curve point) is $174.0 \mathrm{~m}^{3} / \mathrm{s}$, it remains that the flow of the other sub-basins which will not be dampened is given by difference, and is equal to $60.0 \mathrm{~m}^{3} / \mathrm{s}$. Since the allowable flow through the stream channel is $97.5 \mathrm{~m}^{3} / \mathrm{s}$, it is concluded that the maximum allowable flow to be discharged by the initial sub-basins is 37.5 $\mathrm{m}^{3} / \mathrm{s}$. Thus, the reservoir would have to reduce the flow from $114.0 \mathrm{~m}^{3} / \mathrm{s}$ to a value of $37.5 \mathrm{~m}^{3} / \mathrm{s}$, which represents a damping percentage of $67.1 \%$.

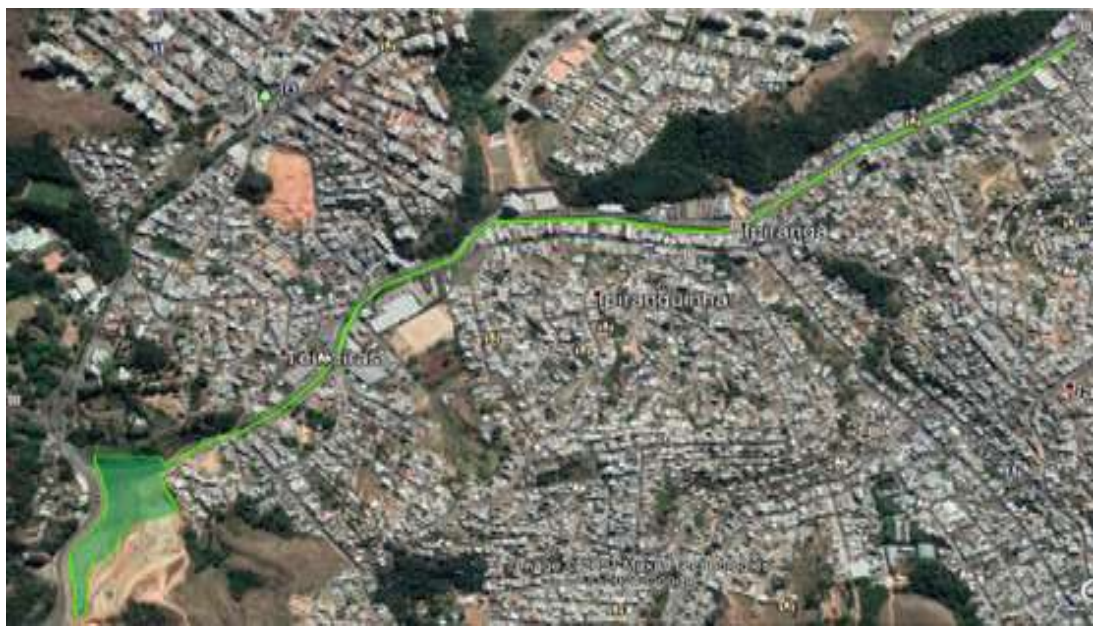

Fig. 3. Optimal positioning for the damping reservoir

\section{Results and Discussion}

From the parameters described in Section 3, the behavior of the damping reservoir was simulated, taking into account, mainly, the issues of effectively available areas and limitation of the maximum height reached by the water depth around 3.0-3.5 m. After some simulations, a combination of quantities that satisfied the imposed restrictions was found. The chosen reservoir had a base area of $30,000 \mathrm{~m}^{2}$, with discharge through 12 bottom holes of $80 \mathrm{~cm}$ in diameter each, with the water rising to a maximum height of $2.92 \mathrm{~m}$. This reservoir provided a discharge with a peak flow of $33.33 \mathrm{~m}^{3} / \mathrm{s}$, lower than the maximum allowed $37.5 \mathrm{~m}^{3} / \mathrm{s}$. The program's input and output schemes are shown in Fig. 4 and Fig. 5, which are, respectively, the input and output datasheets, and in Fig. 6, which expresses the generated smoothing graph.

Damping Reservoir Capacity Calculation
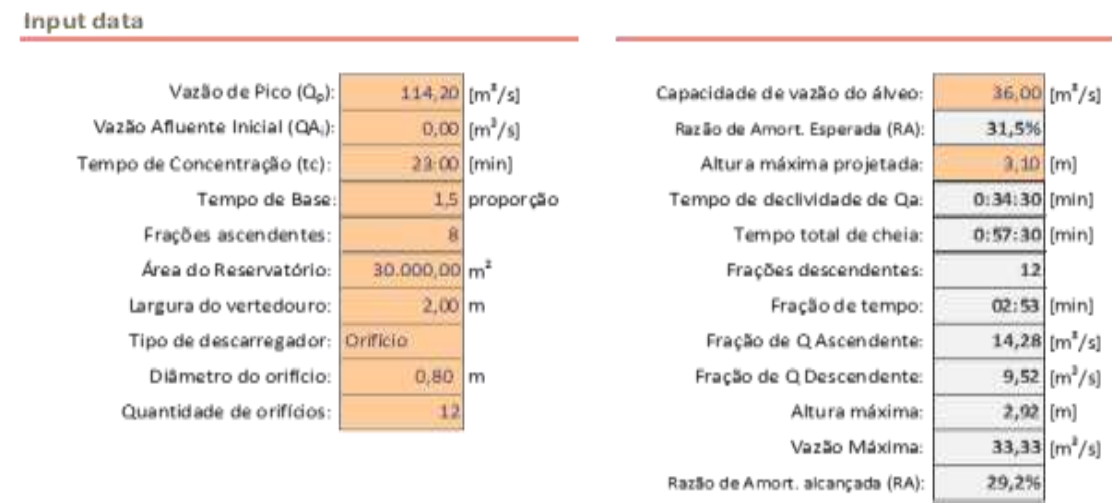

Fig. 4. Input data form 


\begin{tabular}{|c|c|c|c|c|c|c|c|c|c|c|c|}
\hline Finto & 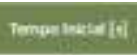 & Ef & ax & es & on & $\mathrm{V}=\mathrm{B}$ & $y_{4}$ & $\propto$ & 5 & 6 & Tenima \\
\hline 2 & 220 & 220 & 390 & 1428 & 10,00 & 000 & EEa 38 & 2.9393 & 6,75 & 85650 & n \\
\hline 2 & 200 & 200 & 14.23 & 2255 & $2, p 2$ & 600, at & 2721.51 & 5,000 & 6,75 & $107, \pi 6$ & 25 \\
\hline 3 & $x=0$ & $2 x$ & IRtF & $2, \pi$ & 100 & 27255 & $\sin 05$ & I.00\% & 5.75 & $6551, \pi$ & $2 \pi$ \\
\hline 4 & 490 & 120 & 42,83 & 57,10 & 8,81 & $6.123,40$ & 20.296 .05 & 11,7412 & 6,75 & $11.590,55$ & 24 \\
\hline 5 & 600 & 120 & 5210 & 7238 & iiis & 20395,06 & 17.009 .46 & 14.5765 & 8,75 & 17.896006 & 25 \\
\hline 6 & no & 120 & 72,35 & s5,6s & $16,6 \mathrm{~s}$ & $17.009,46$ & $24 . \mathrm{EA}, 6 \mathrm{~B}$ & 27,6118 & 6,75 & $25: 590,37$ & 28 \\
\hline 7 & sap & 120 & tan & rags & If & $21491, \mathrm{a}$ & 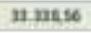 & 20,101 & 4,78 & 34572,42 & It \\
\hline $\mathrm{a}$ & $x 60$ & 120 & $n n$ & 28420 & 20,55 & n1.3n, 66 & 47.544 .24 & $22,4 m 23$ & 6.75 & 4. 251,24 & 26 \\
\hline , & Ine & $3 n$ & nazn & 204 वा & mis & 1anss, 28 & ถา7015 & $260 \mathrm{ma}$ & 6.75 & 55.20930 & 25 \\
\hline 10 & 1200 & 120 & 10468 & 95,17 & 2508 & $53.703,56$ & 62.442 .59 & 28,1201 & 6,75 & $64.129,86$ & 28 \\
\hline is & 1920 & 120 & 7517 & 4,65 & $=11$ & $62,42,50$ & A. & 24,72 & E,75 & 7160438 & 21 \\
\hline 12 & 140 & 120 & es, 65 & 76,13 & 20,73 & $69.220,22$ & $75.885,11$ & 31,00 & 6,75 & $77.743,12$ & 28 \\
\hline a & 200 & 220 & 7041 & 6462 & 7506 & 7nsin,II & Depay & $11 x$ & 4,75 & 12.sas,17 & $2 x$ \\
\hline 24 & 16100 & 1200 & 66,62 & 57,10 & $n x$ & $90,670,20$ & a4.216.18 & 32.6 & 6.75 & $=6.175,66$ & 20 \\
\hline 15 & 1200 & 120 & $57: 10$ & 47,58 & 3396 & 34246.28 & 36551,31 & 33.41 & 4,75 & $88.597,77$ & 27 \\
\hline 16 & 1920 & 120 & 47.58 & 38,07 & 33,11 & 36551,31 & 80.704 .23 & 33.33 & 6,75 & $89.703,92$ & 29 \\
\hline 97 & 20 & in & isat & 2855 & 733 & D) 304,27 & 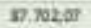 & -9321 & $\$, 75$ & $s=70 \leq 9$ & as \\
\hline is & 2160 & 120 & 23.55 & 19,03 & 35,33 & $80.702,00$ & $96.570,83$ & 33,11 & 6,75 & $88.557,52$ & 2 \\
\hline 13 & 2280 & 130 & 19 : & 952 & 7111 & 56570.83 & 333634 & $32 \mathrm{kE}$ & 8.75 & 86,29722 & $2 t$ \\
\hline 20 & 2400 & 120 & 9,52 & 0,00 & 32.68 & 34336,34 & 81.024.54 & 32,03 & 6,75 & $82,946,53$ & 26 \\
\hline 24 & & & 8,50 & & 3213 & & & & & & \\
\hline
\end{tabular}

Fig. 5. Output data form

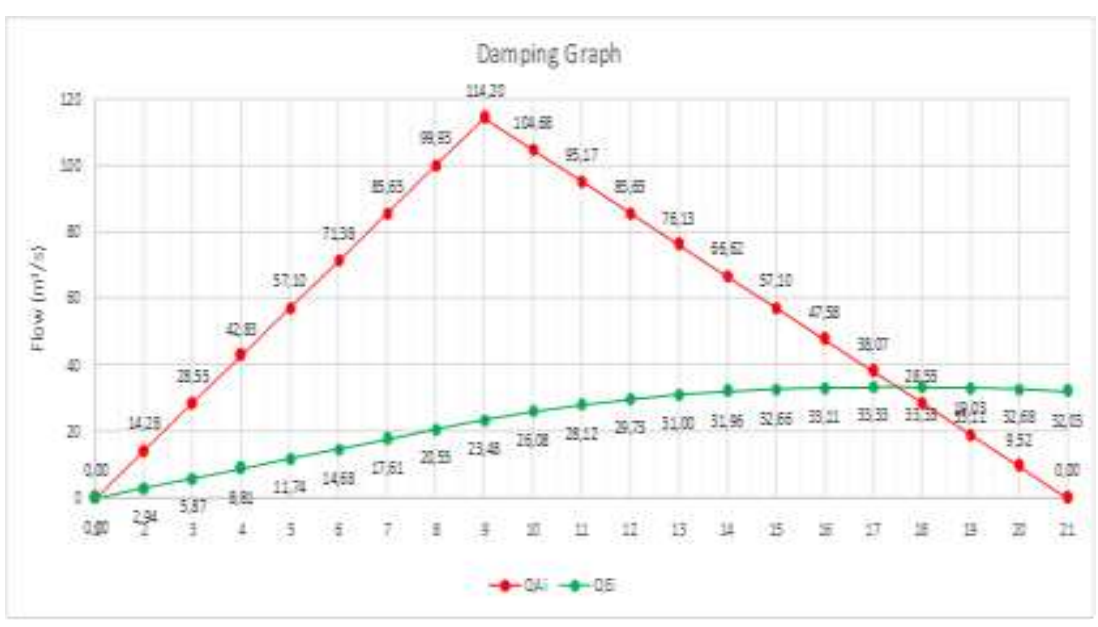

Fig. 6. Graph for damping analysis

\section{Conclusion}

Floods and overflows have an impact on urban transportation and infrastructure, as well as the presence of waterborne infections and the spread of vectors. They also have environmental consequences, such as contaminating urban water sources and lowering their quality. Floods, in more extreme cases, cause critical factors, culminating in the loss of human life. It is feasible to argue that the city of Juiz de Fora has urban circumstances that create a framework vulnerable to problems like flooding and spillovers. These are connected to the region's high rainfall levels and the effects of urbanization-related changes. In this regard, in order to tackle infrastructure challenges such as the one presented in this work, the function of Civil Engineering arises, whose professional is prepared to provide new technical solutions for the improvements to the society. It is up to him to select suitable land, circumstances, materials, and professionals, as well as to design solutions while continually attempting to minimize costs and environmental implications.

Initial parameters were presented for the basic design of a damping reservoir to be installed in order to solve the issue of floods in the Ipiranga Stream basin. These were obtained through an efficient computational tool developed in VBA, to systematize the flood routing process. It is noteworthy that there are still spaces available for the installation of the aforementioned reservoir. However, in view of the accelerated urbanization process, the provisions for making available and reserving the area for such purposes must be taken with some urgency, otherwise, the spaces can be occupied in a short period. If left for the future, there are strong possibilities that the desired solutions will only be achieved by facing much greater obstacles than the current ones, with larger economic, social, and environmental strains. 
Acknowledgments: The first author acknowledges the PIBIC / ESTÁCIO JUIZ DE FORA 2020-2021 program guidance grant.

Conflicts of Interest: The authors declare no conflict of interest.

\section{References}

[1] Kessler, A., \& Diskin, M. H. (1991). The efficiency function of detention reservoirs in urban drainage systems. Water Resources Research, 27(3), 253-258. https://doi.org/10.1029/90WR02143

[2] Fugita, O. (1986). Drenagem urbana - manual de projeto: Planejamento [Urban drainage - design manual: Planning]. Cetesb.

[3] Wilken, P. S. (1978). Engenharia de drainage superficial [Surface drainage engineering]. Cetesb.

[4] Akan, A. O. (1989). Detention pond sizing for multiple return periods. Journal of Hydraulic Engineering, 115(5), 650-664. https://doi.org/10.1061/(ASCE)0733-9429(1989)115:5(650)

[5] Abt, S. R., \& Grigg, N. S. (1978). An approximate method for sizing detention reservoirs. Water Resources Bulletin, 14(4), $956-965$. https://doi.org/10.1111/j.1752-1688.1978.tb05591.x

[6] McEnroe, B. M. (1992). Preliminary sizing of detention reservoirs to reduce peak discharges. Journal of Hydraulic Engineering, 118(11), 15401549. https://doi.org/10.1061/(ASCE)0733-9429(1992)118:11(1540)

[7] Creager, W. P., Justin, J. D., \& Hinds, J. (1945). Engineering for dams. John Wiley \& Sons.

[8] Basha, H. A. (1994). Nonlinear reservoir routing: Particular analytical solution. Journal of Hydraulic Engineering, 120(5), 624-632. https://doi.org/10.1061/(ASCE)0733-9429(1994)120:5(624)

[9] Basha, H. A. (1995). Routing equations for detentions reservoirs. Journal of Hydraulic Engineering, 121(12), 885-888. https://doi.org/10.1061/(ASCE)0733-9429(1995)121:12(885)

[10] Shrestha, B. B., \& Kawasaki A. (2020). Quantitative assessment of flood risk with an evaluation of the effectiveness of dam operation for flood control: A case of the Bago River basin of Myanmar. International Journal of Disaster Risk Reduction, 50, 1-15. https://doi.org/10.1016/j.jidrr.2020.101707

[11] Zhu, F., Zhong, P. A., Sun, Y., \& Yeh, W. W. G. (2017). Real-time optimal flood control decision-making and risk propagation under multiple uncertainties. Water Resources Research, 53, 10,635-10,654. https://doi.org/10.1002/2017WR021480

[12] Rong, Y., Zhang, T., Peng, L., \& Feng, P. (2019). Three-dimensional numerical simulation of dam discharge and flood routing in Wudu reservoir. Water, 11(10), 1-20. https://doi.org/10.3390/w11102157

[13] Milograna, J.; Baptista, M. B.; \& Campana, N. A. (2013). Sistemática para avaliação dos danos diretos decorrentes de inundações à infraestrutura urbana [System for assessment of direct damage from flooding to urban infrastructure]. Revista de Gestão de Água da América Latina, 10(2), 37-50. http://dx.doi.org/10.21168/rega.v10n2.p37-50

[14] Balistrocchi, M., Orlandini, S., Ranzi, R., \& Bacchi, B. (2017). Copula-based modeling of flood control reservoirs. Water Resources Research, 53, 9883-9900. https://doi.org/10.1002/2017WR021345

[15] Zhou, C., Sun, N., Chen, L., Ding, Y., Zhou, J., Zha, G., Luo, G., Dai, L., \& Yang, X. (2018). Optimal operation of cascade reservoirs for flood control of multiple areas downstream: A case study in the upper Yangtze River basin. Water, 10(9), 1-24. https://doi.org/10.3390/w10091250

[16] Antonov, V. I., Badenko, V. L., Davydov, R. V., Maslikov, V. I., \& Molodtsov, D. V. (2019). Modeling parameters of the flood control facilities adapted to climate change. Journal of Physics: Conference Series, 21-22, 1236 012049, 1-7. https://doi.org/10.1088/1742$6596 / 1236 / 1 / 012049$

[17] Gong, Y., Liu, P., Cheng, L., Chen, G., Zhou, Y., Zhang, X., \& Xu, W. (2019). Determining dynamic water level control boundaries for a multireservoir system during flood seasons with considering channel storage. Journal of Flood Risk Management, 13, 1-17. https://doi.org/10.1111/jfr3.12586

[18] Silva, T. R., Miranda, J. M., Andrade Sobrinho, R., \& Neves, R. F. (2014). Implantação de reservatórios de amortecimento no município de Lauro de Freitas (BA) [Implementation of dumpening reservoirs in the Municipality of Lauro de Freitas (BA)]. Proceedings of the Brazilian Groundwater Congress, Brazil, 18. https://aguassubterraneas.abas.org/asubterraneas/article/view/28298

[19] Augusto, D. L. (2008). Concepção, modelagem e detalhamento de um reservatório de detenção em praça, como alternativa para o controle de cheias na bacia do Rio Guerenguê [Conception, modeling and detailing of a detention reservoir in a square, as an alternative for flood control in the Guerenguê River basin] [Master's thesis, Federal University of Rio de Janeiro]. http://www.pec.coppe.ufrj.br/pt/?option=com_docman\&task=doc_download\&gid=1502\&ltemid=

[20] Martins, P. A. G. (2006). Manejo de águas pluviais urbanas: Estudo de bacias de amortecimento na região metropolitana de São Paulo [Urban stormwater management: Study of damping basins in the metropolitan region of São Paulo] [Master's thesis, Pontifical Catholic University of Campinas]. http://tede.bibliotecadigital.puc-campinas.edu.br:8080/jspui/handle/tede/35.

[21] Silva, M. F., Sardinha, D. S, Martins, P. D., \& Poleto, C. (2013). Sistemas de amortecimento de cheias do Parque das Acácias na cidade de Uberaba (MG) [Flood damping systems at the Parque das Acácias in the city of Uberaba MG]. Periódico Eletrônico Fórum Ambiental da Alta Paulista, 9(2), 416-432. https://doi.org/10.17271/19800827922013657

[22] Penna, L., Ribeiro, F., Rocha, C., \& Filho, A. (2019). A utilização de reservatórios no amortecimento de vazões de cheia: Apresentação e discussão de casos do sudeste brasileiro [The use of reservoirs in the dumping of flows: Presentation and discussion of cases from the Brazilian southeast]. Revista de Geografia e Ordenamento do Território, 2019(16), 275-295. http://dx.doi.org/10.17127/got/2019.16.012

[23] Souza, R. C. C. (2018). Método para dimensionamento eficiente de reservatórios de contenção de cheias para a cidade de Curitiba-PR [Method for efficient sizing of flood containment reservoirs for the city of Curitiba-PR] [Master's thesis, Federal Technological University of Paraná]. http://repositorio.utfpr.edu.br/jspui/handle/1/3105

[24] Cruz, M. A. S., Tucci, C. E. M., \& Silveira, A. L. L. (1998). Controle do escoamento com detenção em lotes urbanos [Runuff control with detention in urban lots]. Revista Brasileira de Recursos Hídricos, 3(4), 19-31. http://dx.doi.org/10.21168/rbrh.v3n4.p19-31

[25] Francischet, M. M., \& Alamy Filho, J. E. (2011). Análise da influência dos reservatórios de detenção domiciliares no escoamento superficial urbano aplicados na estimativa de vazões críticas geradas em uma quadra padrão [Analysis of the influence of household detention 
reservoirs on urban surface runoff applied to the estimation of critical flows generated in a standard block]. Proceedings of the Brazilian Symposium on Water Resources, Brazil, 19. https://www.abrhidro.org.br/SGCv3/publicacao.php?PUB=3\&ID=81\&SUMARIO=970

[26] Vanijjirattikhan, R., Thongthamchart, C., Rakcheep, P., Supakchukul, U., \& Suwatthikul, J. (2021). Reservoir flood routing simulation for dam safety management in Thailand. Journal of Disaster Research, 16(4), 596-606. https://doi.org/10.20965/jdr.2021.p0596

[27] Galil, V. M., \& Pizzo, H. S. (2021). Flood damping curve modeling by flood routing method using Visual Basic for Applications - VBA. International Journal of Science and Engineering Investigations, 10(115), 50-55. http://www.ijsei.com/papers/ijsei-1011521-07.pdf

[28] Angelidis, P., Kotsikas, M., Kopasakis, K., Maris, F., \& Kotsovinos, N. (2018). Flood routing simulation and management in hydrologic basins with artificial reservoirs -The case of Arda River. Computational Water, Energy, and Environmental Engineering, 7, 51-68. https://doi.org/10.4236/cweee.2018.72003

[29] Pizzo, H. S. (1997). Reservatórios de amortecimento de cheias em bacias urbanas [Flood dampening reservoirs in urban basins] [Master's thesis, Oswaldo Cruz Foundation].

[30] Cicolani, M. D., \& Pecini, B. (2019). Programa para dimensionar reservatório de amortecimento de enchentes em área urbana com base em planilha Excel com aplicação a um estudo de caso [Program for dimensioning flood damping reservoirs in urban areas based on an Excel spreadsheet with application to a case study]. Proceedings of the Mackenzie Seminar of Scientific Research, Brazil, 15, 1-19. http://eventoscopq.mackenzie.br/index.php/jornada/xvjornada/paper/view/1761

[31] Silva, R. S., \& Machado, P. J. O. (2011). Inundações urbanas: O caso da micro-bacia hidrográfica do Córrego Ipiranga - Juiz de Fora/MG [Urban flooding: The case of the Ipiranga Stream watershed - Juiz de Fora/MG]. Periódico Eletrônico Fórum Ambiental da Alta Paulista, 7(2), 152-165. https://doi.org/10.17271/19800827722011110

[32] City Hall of Juiz de Fora, Federal University of Juiz de Fora, \& Association Pro-Management of the Waters of the Paraíba do Sul River Basin (2011). Plano de drenagem de Juiz de Fora - Parte 1: Zona Norte - Volume 1: Diagnóstico [Juiz de Fora drainage plan - Part 1: North Zone Volume 1: Diagnosis]. https://www.pjf.mg.gov.br/secretarias/sepur/planos_programas/arquivos/diagnostico.pdf

[33] Gerheim, D. K. M. (2016). Alagamentos, enxurradas e inundações na área urbana de Juiz de Fora: Um olhar sobre as bacias hidrográficas dos Córregos São Pedro e Ipiranga [Overflows, flash floods and inundations in the urban area of Juiz de Fora: A look at the hydrographic basins of the São Pedro and Ipiranga Streams] [Undergraduate thesis, Federal University of Juiz de Fora].

[34] Galil, V. M., Pizzo, H. S., Oliveira, W. G., \& Calcaterra, V. F. (2021). Metodologia para determinação de descargas na bacia hidrográfica do Córrego Ipiranga em Juiz de Fora [Methodology for determination of discharges in the Ipiranga Stream basin in Juiz de Fora]. Brazilian Journal of Development, 7(2), 20728-20752. https://doi.org/10.34117/bjdv7n2-629 